\title{
The Transmedia Designer as Mediator of Worlds
}

\author{
Keywords \\ Transmedia Practice, Transmedia Designer, Metadeisgn, Platform, Media Convergence.
}

Media convergence has made the communicative experience increasingly collective and fragmented between different platforms and networks designed for participation. This process was consolidated especially through transmedia practices in the field of arts and entertainment (DENA, 2009), which implemented complex dynamics of storytelling through multiple media supports, reinforcing a greater relationship among the agents involved (public and filmmakers) and the contents that circulate. There is a tendency for media projects to act in an almost emergent manner, marked by constant negotiation between the public and those who project them, acting more as environments or context for consumption and (re)creation of content. We can consider the construction of worlds as something inherent in the current scenario of media production, already taken by a transmedia logic that seeks to involve different audiences through different screens and participatory platforms (such as social networks). In this way, transmedia practice becomes a means of building worlds where contexts are mediated and coordinated between different media supports and platforms - the multiplatform - generating a large integrated transmedia platform. Thus, the action of what is traditionally called a transmedia producer becomes that of a designer who not only plans finished products, he also acts as a mediator of contexts that shape the experience in the project (or world) designed. As José Bártolo (2011, n.p.) argues, the contemporary designer should no longer be recognized as a specialist, who is responsible for finding specific solutions, but as a "critical social agent", who collaborates with non-designer partners in the search for effective transformations in certain aspects of reality. That is, as the worlds created by transmedia practices are interpreted as mediating environments or platforms between different agents, the designer must act as a mediator of actions, focused on experience in its different aspects - in a context in which the "[...] distinctions between production and consumption became blurred" (HOLLOWAY, 2021 , p. 12). From this aspect, this paper seeks to discuss the use of the term transmedia designer, in detriment of transmedia producer, to designate the manager of projects that make coordinated use of a communication ecosystem in order to constitute worlds as platforms for, thus, provide immersive and participatory experiences for the public. Therefore, a bibliographical review will be carried out on the correlations between the field of project design and transmedia practice, in addition to a brief analysis of cross-platform projects, in order to propose concepts for thinking about the role of the transmedia designer from a design thinking of continuous construction of a world as a platform that expands in collaboration with the public. 